\title{
Nesting of Morelet's crocodile, Crocodylus moreletii (Dumeril and Bibron), in Los Tuxtlas, Mexico
}

\author{
A. Villegas ${ }^{a, b, c *}$, G. D. Mendoza $a^{a}$, J. L. Arcos-García ${ }^{d}$ and V. H. Reynoso \\ aDepartamento de Producción Agrícola y Animal, Universidad Autónoma Metropolitana, Unidad Xochimilco, \\ Calzada del Hueso, 1100, Col. Villa Quietud, Del. Coyoacán, CP 04960, Ciudad de México, México

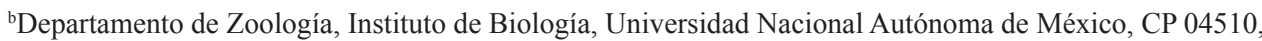 \\ Ciudad de México, México \\ 'Departamento de Biología Comparada, Facultad de Ciencias, Universidad Nacional Autónoma de México, CP 04510, \\ Ciudad de México, México \\ dInstituto de Ecología, Universidad del Mar, Campus Puerto Escondido, Ciudad Universitaria, CP 71980, \\ Puerto Escondido, Oaxaca, México \\ *e-mail: alejandrovillegasmx@yahoo.com
}

Received: October 30, 2015 - Accepted: June 16, 2016 - Distributed: November 31, 2017

(With 4 figures)

$\uparrow$ In Memory of Carlos Rodríguez Elías (Caco), an active conservationist and founder of the "Reserva Ecológica Nanciyaga" in Los Tuxtlas.

\begin{abstract}
We evaluated the nesting by Crocodylus moreletii in Lago de Catemaco, Veracruz, southeastern, Mexico. During the nesting and hatching seasons, we searched for nests along the northern margins of the lake and small associated streams. We investigated egg mortality by weekly monitoring each of the nests found, recording sign of predation (tracks and holes dug into the nest) and the effect of water level fluctuations. We not found differences to nest between inland or flooded zones. However, we found that egg size varied among nests. In nests built inland, predation was the major cause of egg mortality whereas flooding resulted in more deaths of eggs in the flooding zone. Flooding killed $25 \%$ of eggs monitored in this study. We suggest that to increase nest success in the Morelet's crocodile it is necessary to promote conservation of nesting areas around the lake, recently occupied by urban or tourist developments.
\end{abstract}

Keywords: crocodile, egg mortality, flooding, Mexico, predation.

\section{Nidificação de crocodilo do Morelet, Crocodylus moreletii (Dumeril e Bibron), em Los Tuxtlas, México}

\section{Resumo}

Nós avaliamos a nidificação numa população de Crocodylus moreletii no Lago de Catemaco, Veracruz, sudeste, México. Durante as temporadas de nidificação e eclosão buscamos ninhos ao longo das margens situadas ao norte do lago e pequenos riachos associados. Estabelecemos a mortalidade de ovos por semana monitorando cada ninho achado, registrando qualquer sinal de predação (rastros e buracos cavados no ninho) e o efeito das flutuações no nível da agua. Não achamos nenhuma preferência para aninhar na terra ou em áreas inundadas. Por outro lado, achamos que o tamanho de ovo foi significativamente diferente entre os tipos de ninho. Em ninhos construídos na terra, a predação foi a principal causa da mortalidade de ovos enquanto que nas áreas inundadas, inundação foi um fator importante na morte dos ovos. Em comparação com depredação, a ruptura acidental e colonização fúngica, as inundações mataram $25 \%$ de ovos monitorados. Nós sugerimos que para aumentar o sucesso de aninhamento do crocodilo do Morelet é preciso promover a conservação das áreas de nidificação ao redor do lago, recentemente ocupadas pelo desenvolvimento urbano ou turístico.

Palavras-chave: crocodilo, mortalidade de ovos, inundação, México, predação.

\section{Introduction}

Morelet's crocodile, Crocodylus moreletii, inhabits swamps, lakes and rivers bodies along the Gulf of Mexico and the Yucatan Peninsula (Cedeño-Vázquez et al., 2006;
Escobedo-Galván and González-Salazar, 2011), Guatemala and Belize (Ross, 1998). The species is protected by the Mexican legislation (NOM-059-ECOL-2010), is considered 
of "Least Concern" by the International Union for the Conservancy of Nature (IUCN) Red List, and listed in Appendix II of the Convention of the International Trade in Endangered Species of Wild Flora and Fauna (CITES) except for the Guatemalan populations (CITES, 2017). There is an increasing interest in sustainable use and captive breeding of this species in Mexico, and assessment of its current status and development of effective management and conservation programs are urgently needed. A population monitoring project and long-term ecological studies must be implemented (Ross, 1998). Descriptions of the ecology including distribution and abundance associated with studies of population dynamics are usually the first step in obtaining basic information for its management (Thorbjarnarson and Hernández, 1993). Studies are basic during nesting season, considered the most vulnerable period in crocodiles' life (Mazzotti, 1989). Morelet's crocodile is the only Crocodylus species in the New World that only builds plant debris mound nests (Thorbjarnarson, 1996). There are few studies focused on nesting of $C$. moreletii in wild populations. Pérez-Higareda (1980) recorded the first floating nests in Veracruz, Platt et al. (2008) studied reproductive biology in Belize, Escobedo-Galván et al. (2011) described nesting activity in northern Mexico and López-Luna et al. (2011) recorded nesting in a highly disturbed ecosystem. Generally the reptiles, facing environmental factors may differently affect the hatching success of different populations, factors such as flooding (Alho and Pádua, 1982; Pezzuti and Vogt, 1999, incubation temperature (Ferreira Júnior and Castro, 2010), soil moisture (Packard et al., 1987), and type of soil (Packard and Packard, 1997) may affect hatching success. We studied the nesting and the causes of egg mortality of C. moreletii in Lago de Catemaco, southern Mexico.

\section{Materials and Methods}

Fieldwork was conducted during 2008 along the northern shore of Lago de Catemaco (18²6’N; 9504'W; 340 m a.s.l.; see Figure 1) and associated streams, in the southeastern of Mexico. The lake surroundings are covered by tropical rainforest and deciduous tropical forest mixed with large anthropogenic grassland areas used for cattle and urban or tourist developments (Mexico, 2007). Mean monthly temperature and precipitation data were obtained from the meteorological station at the Estación de Biología Tropical "Los Tuxtlas" of the Universidad Nacional Autónoma de México (UNAM), from April to September, spanning the nesting and hatching seasons of $C$. moreletii.

Sampling was conducted during 180 hours by kayaking near the shore or walking around the lake and along small-river margins, nests were searched on sites where there have been previously by Pérez-Higareda (1980).

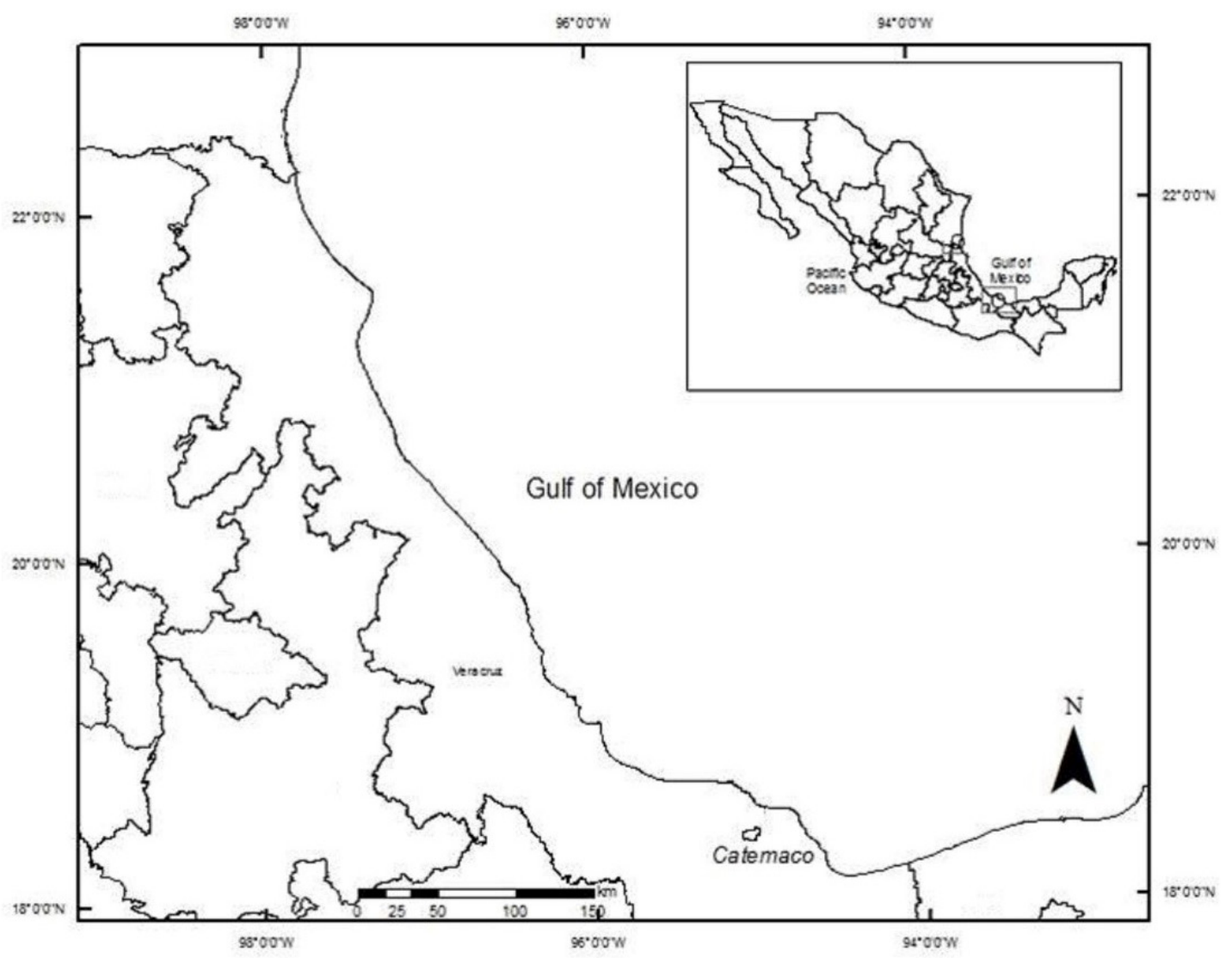

Figure 1. Location of the study area in Lago de Catemaco, Los Tuxtlas, Veracruz. 
We measured height, width and distance from the nest center to the water for all nests (according to Platt et al., 2008). The nests were opened carefully to determine clutch size and the length, width (with a caliper $\pm 1 \mathrm{~mm}$ ) and mass (with a scale $\pm 1 \mathrm{~g}$ ) of each egg. Viable eggs were detected by the opaque band around the shell (Ferguson, 1985). Simple regression analyses were undertaken to evaluate the relationships between nesting features and clutch size; and chi-squared tests were used to analyze differences in nesting site selection (according to Thorbjarnarson and Hernández, 1993, and Thorbjarnarson, 1994). Differences in clutch size, width, length and egg mass among nests were established using Kruskal-Wallis tests and Mann Whitney post hoc tests. To determine the final fate of the eggs, each nest was monitored weekly during the nesting season looking for signs of predation, such as footprints or nest disturbance (Mazzotti, 1989). The distance of to the base of each nest was recorded at each visit.

\section{Results}

Nests were constructed form the end of April to May. The females nested immediately after the first rainfall of the wet season. The average precipitation during these two months was $22.9 \mathrm{~mm}$. The flooding zone was characterized by emergent rooted vegetation associated to commonly-observed macrophytic vegetation. We found that an important flooding peak occurred in June while the eggs were still incubating, and the rainfall overall increased in September after egg hatching. The incubation period was of approximately 90 days, from May to August. Three nests in the flooding zone were flooded during a heavy rain period that increased the water level of the lake; two of these nests were completely lost. Nests loss due to predation was detected in two nests. We located 12 nests, 7 during the nesting season and 5 after hatching season (Figure 2).

Three of the nests were built between the highest and lowest seasonal levels of water; and nine were built inland (tropical rainforest vegetation or sedges around most nests). Two inland nests consisted of a cavity about $30 \mathrm{~cm}$ deep, but one of these was a false nest (no egg in the nest), and was not included in analyses (Table 1). In the inland zone, nests were built with all available organic matter (leaf litter, wood, plant debris). No significant differences were found between the female nesting site between inland zones than flooding zones $\left(\chi^{2}=3, \mathrm{p}=0.083, \mathrm{df}=1\right)$.

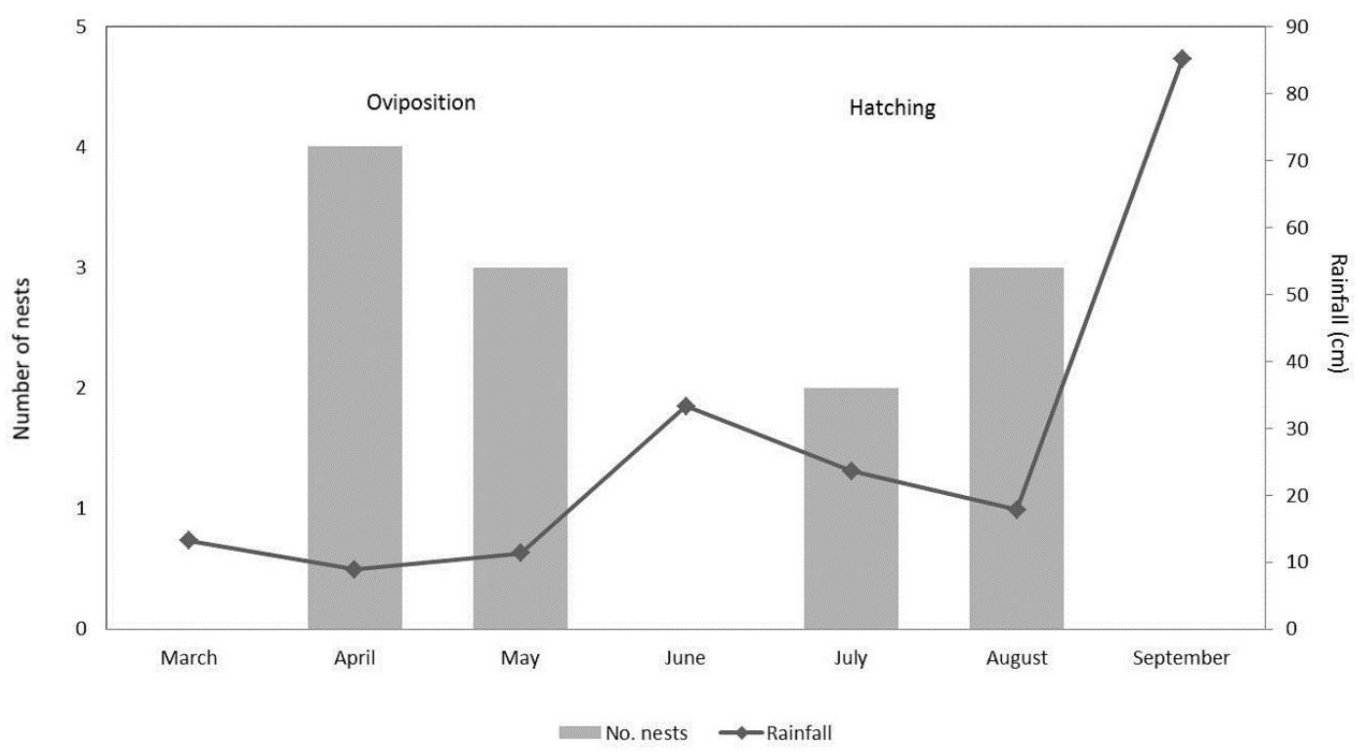

Figure 2. Oviposition and hatching timing in relation to rainfall.

Table 1. Data for Crocodylus moreletii nests found near Lago de Catemaco before hatching.

\begin{tabular}{llcccc}
\hline \multicolumn{1}{c}{ Place } & \multicolumn{1}{c}{ Construction material } & $\begin{array}{c}\text { Nest height } \\
(\mathbf{c m})\end{array}$ & $\begin{array}{c}\text { Nest width } \\
(\mathbf{c m})\end{array}$ & $\begin{array}{c}\text { Distance to } \\
\text { water }(\mathbf{m})\end{array}$ & Flooded eggs \\
\hline Flooding zone & Emergent macrophyte & 45 & 140 & 0 & 35 \\
Inland zone & Leaf litter & 75 & 220 & 1 & 0 \\
Flooding zone & Emergent macrophyte & 45 & 135 & 0 & 35 \\
Inland zone & Leaf litter & 40 & 86 & 10 & 0 \\
Inland zone & Leaf litter & 35 & 160 & 2.60 & 0 \\
Inland zone* & Soil and leaf litter & 18 & 128 & 2.50 & 0 \\
\hline
\end{tabular}

*Nest in a cavity. 
Clutch size ranged from 22 to 35 eggs $(n=6)$ and egg viability was $93.7 \%(n=12)$. Egg width range was $40-47 \mathrm{~mm}(\mathrm{n}=189$ eggs), egg length range was $59-79 \mathrm{~mm}(\mathrm{n}=189 \mathrm{eggs})$ and egg mass range was $73-112 \mathrm{~g}$ ( $\mathrm{n}=189$ eggs). We found significant differences in egg size between nests (Table 2).

Two groups were distinguished when correlating size variables (Figure 3), one consisting of lighter eggs (nests 1 and 6: mass range 73-82 g) and one of heavier eggs (nests 2-5: mass range 98-112 g). Analyzing both groups independently, egg length vs. mass correlation was significant for the lighter eggs $\left(r^{2}=0.67, p<0.0001\right)$, and weak but significant for the heavier eggs $\left(r^{2}=0.26\right.$, $\mathrm{p}<0.0001$ ). Results for the width vs. mass correlations with the lighter eggs have a positive significant correlation $\left(r^{2}=0.41, p<0.0001\right)$, and the heavier eggs have no correlation $\left(\mathrm{r}^{2}=0.05, \mathrm{p}<0.0001\right)$. The correlation between length and width resulted in a single group with

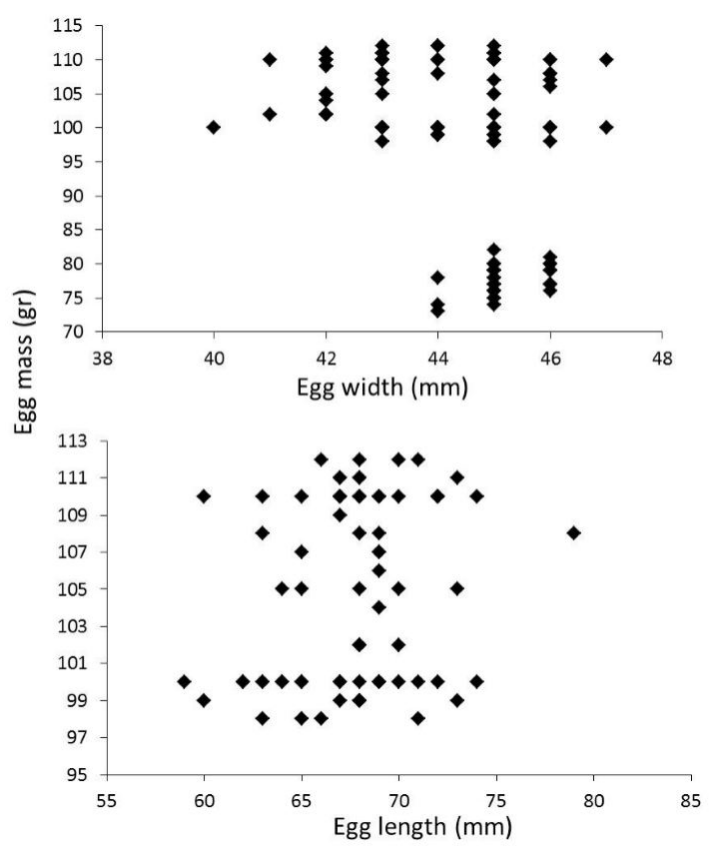

Figure 3. Plots of clutch characteristics relation of egg mas and egg width and length size. both parameters highly correlated $\left(r^{2}=0.42, p<0.0001\right)$. We did find a negative correlation between mean clutch mass and clutch size $\left(r^{2}=-0.34, p<0.0001\right)$, a significant no correlation between clutch size and mean egg width and egg length $\left(r^{2}=-0.16, p<0.0001 ; r^{2}=-0.19, p<0.0001\right.$, respectively) or clutch mean mass and mean egg width and length $\left(r^{2}=-0.82, p=0.008 ; r^{2}=-0.76, p=0.0003\right.$, respectively). Concerning the characteristics of nests and eggs, no significant correlations were found (Figure 4) between mean egg width and nest height $\left(r^{2}=0.74\right.$, $\mathrm{p}=0.455)$, nest width $\left(\mathrm{r}^{2}=0.63, \mathrm{p}=0.007\right)$, and with distance to water $\left(r^{2}=0.42, p=0.047\right)$. Neither found significant correlations between mean egg length and height $\left(r^{2}=0.79, p=0.019\right)$, nest width $\left(r^{2}=0.43, p=0.034\right)$, and with distance to water $\left(\mathrm{r}^{2}=0.73, \mathrm{p}=0.060\right)$.

Our predicted egg survival rate was as low as $35.4 \%$, as determinate by contrasting hatched eggshell found in the nests, which are relatively easily distinguished, against the partially flooded or eggs taken by predators. We found breakage of the eggs in the deepest part of the nest, was likely also caused by compression $(12.1 \%, \mathrm{n}=189)$, and some of these eggs showed signs of fungal colonization $(4.2 \%, n=189)$. Fungal infection could have occurred on eggs found dead for unknown reasons. Opossum (Didelphis marsupialis) tracks were found on one nest and an opossum was observed around $4 \mathrm{~m}$ from it. In other two nests, we found 16 and 8 predated crocodile eggshells, respectively, although it was impossible to know how many eggs survived for each nest. During the hatching period we navigated along the shore of the lake near the nesting sites and no hatchlings were sighted nearby.

\section{Discussion}

The nesting season coincided with the beginning of the rainy season as reported for this species throughout its range (Platt et al., 2008; Álvarez del Toro, 1974). In Lago de Catemaco most nests had nest shapes similar to those reported by Álvarez del Toro (1974), Hunt (1975), Pérez-Higareda (1980) and López-Luna et al. (2011). In Belize, nests are normally found amongst terrestrial vegetation, but Platt et al. (2008) found one nest that was over floating vegetation and two that were dug in the ground, as the only reported here. Campbell (1972) also reported nests

Table 2. Clutch size, width, length and mass ranges of eggs from C. moreletii nests.

\begin{tabular}{|c|c|c|c|c|}
\hline & Clutch size & Width & Length & Mass \\
\hline & 35 & $47-44^{a}$ & $76-68^{a}$ & $82-73^{b}$ \\
\hline & 22 & $47-41^{\mathrm{ab}}$ & $79-65^{\mathrm{ab}}$ & $110-99^{c}$ \\
\hline & 35 & $46-41^{d}$ & $73-65^{b}$ & $112-98^{\mathrm{a}}$ \\
\hline & 32 & $46-41^{\mathrm{ac}}$ & $73-65^{a}$ & $112-98^{a}$ \\
\hline & 33 & $47-40^{\mathrm{e}}$ & $79-59^{c}$ & $110-98^{\mathrm{d}}$ \\
\hline & 32 & $46-44^{\mathrm{abc}}$ & $75-68^{d}$ & $81-73^{e}$ \\
\hline Mean & $31.5 \pm 4.84$ & $44.3 \pm 1.46$ & $69.2 \pm 3.31$ & $104 \pm 4.93$ \\
\hline Kruskal-Wallis & & $70.20 *$ & $60.29 *$ & $92.77 *$ \\
\hline
\end{tabular}

Differences $(\mathrm{p}<0.05)$ after Kruskal-Wallis tests are indicated by an asterisk $\left(^{*}\right)$ and superscript literals $(\mathrm{a}, \mathrm{b}, \mathrm{c}, \mathrm{d}, \mathrm{e})$ indicate Mann Whitney post hoc differences $(\mathrm{p}<0.05)$. 

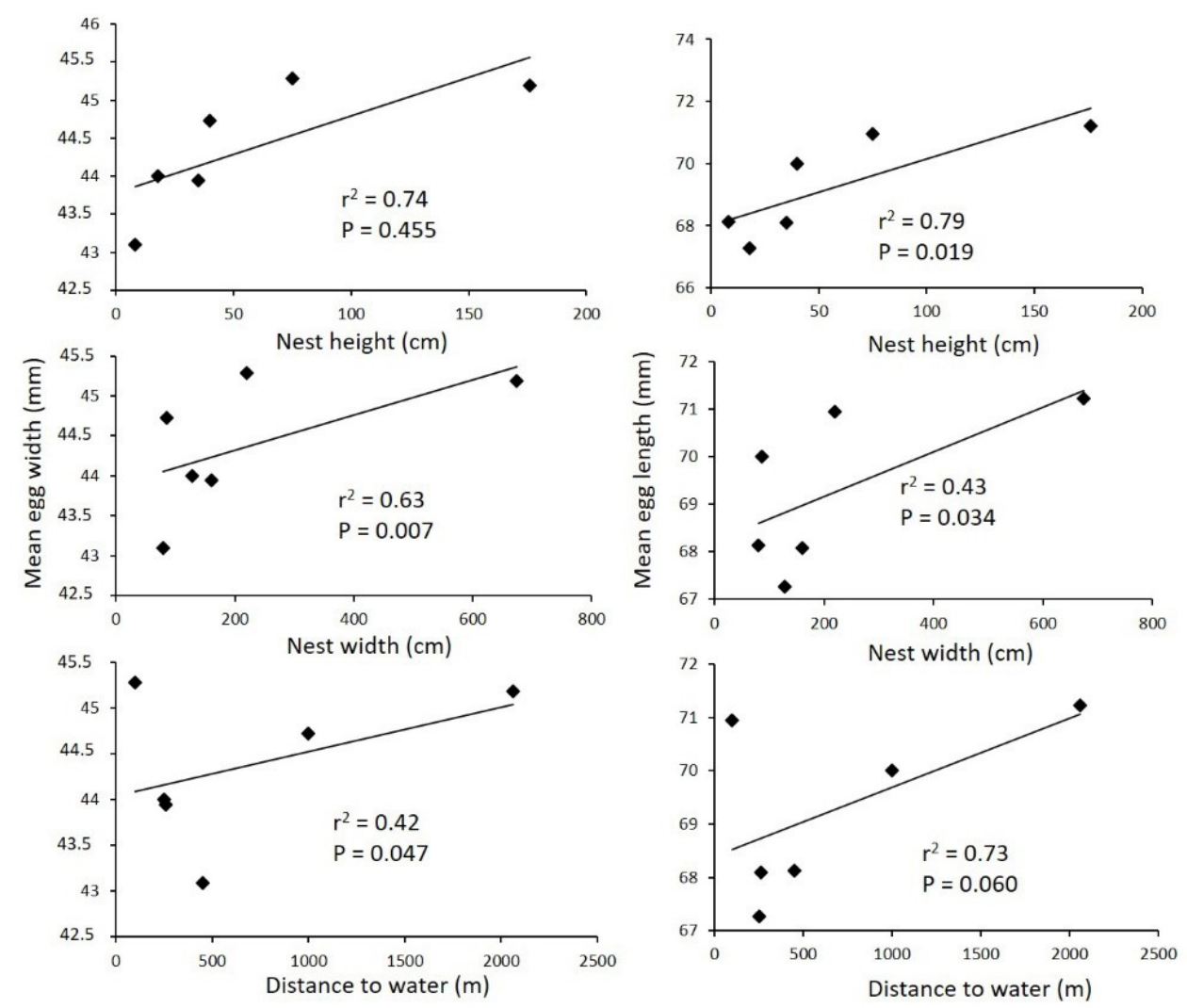

Figure 4. Plots of regression between clutch and nests characteristics of Moleret's crocodile.

within concavities for $C$. moreletii in Mexico. Platt et al. (2008) argued that nests built in concavities are a result of atypical nesting behavior, and suggested that these nests could result from a behavioral mix of C. moreletii $+\mathrm{C}$. acutus hybrids. In Belize, none of the two nests found in concavities was successful. In Los Tuxtlas, is only present C. moreletii, suggesting that hole nesting behavior may be occasional in this species without any hybridization. The median and average nest height and width found in mainland nests (see Table 1) were very similar to the average reported by Platt et al. (2008) and López-Luna et al. (2011). The number of non-viable eggs (excluding broken or rotten eggs) was low, as reported by other authors for C. moreletii. Platt et al. (2008) found $8.7 \%$ of non-viable eggs in Belize and Escobedo-Galván et al. (2011) did not find any in San Luis Potosí, Mexico.

Flooding was limited to $25 \%$ nests built within the flooding zone. This result is similar to data of Platt et al. (2008) who found $27 \%$ of all C. moreletii nests flooded in Belize. As in other reptiles nesting near water bodies, they search for the most suitable sites for nesting, females must choose sites that are topographically high enough to prevent the flooding of nests at the start of the rainy season (Gomes and Ferreira Júnior, 2011; Alves-Júnior et al., 2012). The rise in the water level of Lago de Catemaco is caused by rainfall excess, but we believe that the dam control in the lake may constitute a threat to the crocodile populations.

The clutch-size range was within that found by Casas-Andreu and Rogel-Bahena (1984), Greer (1975), Hunt (1973) and Álvarez del Toro (1974) for C. moreletii in captivity, and Platt et al. (2008) and López-Luna et al. (2011) in the wild in Belize and Tabasco, respectively. Egg-length range was also within that reported for the Belizean crocodile population; but mass ranges differed considerably from those of Platt et al. (2008) who reported mass values lower than ours, with most of their eggs within our light-egg group data. Verdade (2001), reported for broad-snouted caiman Caiman latirostris, larger females tend to produce heavier (instead of more numerous) offspring. Staton and Dixon (1977) and Webb et al. (1977) also found no correlation between clutch size and average egg mass for Caiman crocodilus and Crocodylus porosus, respectively. Dietz and Hines (1980) suggested that for all crocodilians, the total clutch mass is better correlated with egg size than is egg number. Ford and Seigel (1989) stated that no general patterns for reptiles are apparent, especially considering that variation also occurs among populations, and among years within populations.

Egg-survival rate has been poorly measured in wild crocodiles. Hussain (2006) reported 97\% survival in wild Gavialis gangeticus, but for C. moreletii, hatching success 
is lower, ranging from only $50.8 \%$ in Belize (Platt et al., 2008), up to $69.2 \%$ and $80 \%$ in 2007 and 2008 respectively, in Tabasco (López-Luna et al., 2011).

We found no correlation between the mean egg width and length and height and width of the nest, Platt et al. (2008) also found a correlation between eggs and nests characteristics in this specie in Belize. We found no correlation with measures of eggs and the distance from the nest to the water. Platt et al. (2008), started the position of $C$. moreletii nests relative to water varied considerably in northern Belize. Nest positioning probably reflects a balance between placing the nest far enough from water to minimize the risk of flooding

Raccoons (Procyon lotor) are major nest predators (Platt et al., 2008; Mazzotti, 1989), but in Lago de Catemaco opossums were the main crocodile-egg predators. Adult female crocodiles guarding their nests may be very important for nest protection, but regular disturbances originated by human activities and tourism can cause the adult females to abandon their nests or to stay away for longer periods of time (Magnusson, 1982). This has been reported as the main cause favoring nest predation in C. niloticus (Cott, 1969) and we believe that this may be happening in Lago de Catemaco. Fungal colonization is correlated to broken eggs since fungi normally colonize after yolk exposure and egg decomposition. Actual causes of egg death are unknown and fungi may not directly cause it. In any case, the number of eggs attacked by fungi was low.

Magnusson (1982) stated that nests that are not predated or flooded are the ones that contribute with newborns every year, and these few survivors should maintain the population in the long term. Graham (1968) stated that large clutch size and long period of reproductive activity can maintain a stable population even when mortality of hatchlings reaches $99 \%$. However, this stability will depend only on the existence of enough reproductive females in the system. Reproduction represents the only way to prevent any population from disappearing. It is important to develop a conservation strategy particularly for the protection of reproductive adults (Kushlan, 1988). In Lago de Catemaco, the protection of nesting sites would be the best conservation strategy to preserve the Morelet's crocodile population. It becomes necessary to prevent land use changes in areas where crocodiles are still reproducing and to create protected areas for reproduction.

\section{Acknowledgements}

We thank the Nanciyaga Ecological Reserve, especially to late Carlos Rodríguez Elías (Caco)†, Belem Pedraza and Carlos Rodríguez. Frank Mazzotti donated some of the equipment used; John Thorbjarnarson suggested techniques for nest manipulation. First author received a fellowship number 168983 of CONACYT for this project. Melissa Plasman and Héctor Alcántara (a native English speaker, in spite of his Spanish name) went through the English. This project was done with SEMARNAT special collecting permit number SGPA/DGVS/03544/08 to VHR.

\section{References}

ALHO, C.J. and PÁDUA, L.F.M., 1982. Reprodutive parameters and nesting behaviour of the Amazon turtle Podocnemis expansa (Testudinata: Pelomedusidae) in Brazil. Canadian Journal of Zoology, vol. 60, no. 2, pp. 97-103. http://dx.doi.org/10.1139/ z82-012.

ÁlVAREZ DEL TORO, M., 1974. Los Crocodylia de México. México: Instituto Mexicano de Recursos Naturales Renovables. 70 p.

ALVES-JÚNIOR, J.R.F.A., LUSTOSA, A.P.G.B., BOSSO, A.C.S.C., BALESTRA, R.A.M.B., BASTOS, L.F.B., MIRANDA, L.B.D. and SANTOS, A.L.Q., 2012. Reproductive indices in natural nests of giant Amazon river turtles Podocnemis expansa (Schweigger, 1812) (Testudines, Podocnemididae) in the Environmental Protection Area Meanders of the Araguaia river. Brazilian Journal of Biology $=$ Revista Brasileira de Biologia, vol. 72, no. 1, pp. 199-203. PMid:22437402. http://dx.doi.org/10.1590/ S1519-69842012000100024.

CAMPBELL, H.W., 1972. Ecological or phylogenetic interpretations of crocodilian nesting habits. Nature, vol. 238, no. 5364, pp. 404-405. http://dx.doi.org/10.1038/238404a0.

CASAS-ANDREU, G., ROGEL-BAHENA, A., 1984. Observaciones sobre los nidos y las nidadas de Crocodylus moreletii en México. Anales del Instituto de Ciencias de Mar y Limnología, Universidad Nacional Autónoma de México. Serie Zoología, no. 13, pp. 123-303.

CEDEÑO-VÁZQUEZ, J.R., ROSS, J.P. and CALMÉ, S., 2006. Population status and distribution of Crocodylus acutus and C. moreletii in southeastern Quintana Roo, México. Herpetological Natural History, vol. 10, no. 1, pp. 53-66.

CITES, 2017 [viewed 1 Jan 2017]. Checklist of CITES species. Available from: www.checklist.cites.org.

COTT, A.B., 1969. Scientific results of an inquiry into the ecology and economic status of the Nile Crocodile (Crocodylus niloticus) in Uganda and northern Rhodesia. Transactions of the Zoological Society of London, vol. 29, no. 4, pp. 211-356. http:// dx.doi.org/10.1111/j.1096-3642.1961.tb00220.x.

DIETZ, D.C. and HINES, T.C., 1980. Alligator nesting in north central Florida. Copeia, vol. 1980, no. 2, pp. 249-528. http:// dx.doi.org/10.2307/1444001.

ESCOBEDO-GALVÁN, A.H. and GONZÁLEZ-SALAZAR, C., 2011. Aplicando modelos de nicho ecológico para predecir áreas potenciales de hibridación entre Crocodylus acutus y C. moreletii. Revista Quehacer Cientifico en Chiapas, vol. 1, no. 11, pp. 27-35.

ESCOBEDO-GALVÁN, A.H., CASAS-ANDREU, G., BARRIOSQUIROZ, G., SUSTAITA-RODRÍGUEZ, V.H. and LÓPEZ-LUNA, M.A., 2011. Observations on nests of Crocodylus moreletii in San Luis Potosí, México. Revista Mexicana de Biodiversidad, vol. 82 , no. 1 , pp. 315-317.

FERGUSON, M.W.J., 1985. Reproductive biology and embryology of the crocodilians. In: A.C. GANS, F. BILLET and P.F.A. MADERSON, eds. Biology of the reptilia development. New York: John Wiley and Sons, vol. 14, pp. 329-491.

FERREIRA JÚNIOR, P.D. and CASTRO, P.T.A., 2010. Nesting ecology of Podocnemis expansa (Schweigger, 1812) and Podocnemis unifilis (Troschel, 1848) (Testudines, Podocnemididae) in the Javaés River, Brazil. Brazilian Journal of Biology $=$ Revista Brasileira de Biologia, vol. 70, no. 1, pp. 85-94. PMid:20231963. http:// dx.doi.org/10.1590/S1519-69842010000100012. 
FORD, N.B. and SEIGEL, R.A., 1989. Relationships among body size, clutch size and egg size in three species of oviparous snakes. Herpetologica, vol. 45, no. 1, pp. 75-83.

GOMES, A.S. and FERREIRA JÚNIOR, P.D., 2011. Management and relocation of nests of Podocnemis expansa (Schweigger, 1812) (Testudines, Podocnemididae) on the Crixás-Açu River, Brazil. Brazilian Journal of Biology $=$ Revista Brasileira de Biologia, vol. 71, no. 4, pp. 975-982. http://dx.doi.org/10.1590/ S1519-69842011000500017.

GRAHAM, A., 1968. The Lake Rudolph crocodile (Crocodylus niloticus Laurenti) population. Kenya: Kenya Game Department. 145 p. Report to the Kenya Game Commission.

GREER, A.E., 1975. Clutch size in crocodilians. Journal of Herpetology, vol. 9, no. 3, pp. 319-322. http://dx.doi. org/10.2307/1563198.

HUNT, R.H., 1973. Breeding Morelet's crocodile. International Zoo Yearbook, vol. 13, no. 1, pp. 103-105. http://dx.doi. org/10.1111/j.1748-1090.1973.tb02113.x.

HUNT, R.H., 1975. Maternal behavior in the Morelet's crocodile, Crocodylus moreletii. Copeia, vol. 1975, no. 4, pp. 763-764. http://dx.doi.org/10.2307/1443329.

HUSSAIN, S.A., 2006. Reproductive success, hatchling survival and rate of increase of gharial Gavialis gangeticus in National Chambal Sanctuary, India. Biological Conservation, vol. 87, no. 2, pp. 261-268. http://dx.doi.org/10.1016/S0006-3207(98)00065-2.

KUSHLAN, J.A., 1988. Conservation and management of the American crocodile. Environmental Management, vol. 12, no. 6, pp. 777-790. http://dx.doi.org/10.1007/BF01867604.

LÓPEZ-LUNA, M.A., HIDALGO-MIHART, M.G. and AGUIRRELEÓN, G., 2011. Descripción de los nidos del cocodrilo de pantano Crocodylus moreletii en un paisaje urbanizado en el sureste de México. Acta Zoológica Mexicana, vol. 27, no. 1, pp. 1-6.

MAGNUSSON, W.E., 1982. Mortality of eggs of the Crocodile Crocodylus porosus in Northern Australia. Journal of Herpetology, vol. 16, no. 2, pp. 121-130. http://dx.doi.org/10.2307/1563804.

MAZZOTTI, F.J., 1989. Factors affecting the nesting success of the American crocodile, Crocodylus acutus, in Florida bay. Bulletin of Marine Science, vol. 44, no. 1, pp. 220-228.

MEXICO, 2007. Norma Oficial Mexicana NOM-041-PESC-2004, Pesca responsable en el lago de Catemaco, ubicado en el Estado de Veracruz. Especificaciones para el aprovechamiento de los recursos pesqueros. Diario Oficial, México, DF.

PACKARD, G.C. and PACKARD, M.J., 1997. Type of soil affects survival by overwintering hatchlings of painted turtle.
Journal of Thermal Biology, vol. 22, no. 1, pp. 53-58. http:// dx.doi.org/10.1016/S0306-4565(96)00034-4.

PACKARD, G.C., PACKARD, M.J., MILLER, K. and BOARDMAN, T.J., 1987. Influence of moisture, temperature, and substrate on snapping turtle eggs and embryos. Ecology, vol. 68, no. 4, pp. 983-993. http://dx.doi.org/10.2307/1938369.

PÉREZ-HIGAREDA, G., 1980. Notes on nesting of Crocodylus moreletii in southern Veracruz, Mexico. Bulletin of the Maryland Herpetological Society, vol. 16, no. 2, pp. 52-53.

PEZZUTI, J.C.B. and VOGT, R.C., 1999. Nesting ecology of Podocnemis sextuberculata (Testudines, Pelomedusidae) in the Japurá River, Amazonas, Brazil. Chelonian Conservation and Biology, vol. 3, no. 3, pp. 419-424.

PLATT, S.G., RAINWATER, T.R., THORBJARNARSON, J.B. and MCMURRY, S.T., 2008. Reproductive dynamics of a tropical freshwater crocodilian: Morelet's crocodile in northern Belize. Journal of Zoology, vol. 275, no. 2, pp. 177-189. http://dx.doi. org/10.1111/j.1469-7998.2008.00426.x.

ROSS, J.P., 1998. Crocodiles: status surveys and conservation action plan. 2nd ed. Gland, Switzerland: IUCN/SSC Crocodile Specialist Group. 96 p.

STATON, M.A. and DIXON, J.R., 1977. Breeding biology of the spectacled caiman, Caiman crocodilus crocodilus, in Venezuelan llanos. Washington, DC: Deptartment of Interior Fish and Wildlife Service. 21 p. Wildlife Research Report, no. 5.

THORBJARNARSON, J.B., 1994. Reproductive ecology of the spectacled caiman (Caiman crocodilus) in the Venezuelan Llanos. Copeia, vol. 1994, no. 4, pp. 907-919. http://dx.doi. org/10.2307/1446713.

THORBJARNARSON, J.B., 1996. Reproductive characteristics of the Order Crocodylia. Herpetologica, vol. 52, pp. 8-24.

THORBJARNARSON, J.B. and HERNÁNDEZ, G., 1993. Reproductive ecology of the Orinoco crocodile (Crocodylus intermedius) in Venezuela. I. Nesting ecology and egg and clutch relationships. Journal of Herpetology, vol. 27, no. 4, pp. 363-370. http://dx.doi.org/10.2307/1564821.

VERDADE, L.M., 2001. Allometry of reproduction in broadsnouted caiman (Caiman latirostris). Brazilian Journal of Biology $=$ Revista Brasileira de Biologia, vol. 61, no. 3, pp. 431-435. PMid:11706570. http://dx.doi.org/10.1590/S151969842001000300012.

WEBB, G.J.W., MESSEL, H. and MAGNUSSON, W.E., 1977. The nesting of Crocodylus porosus in Arhem Land, Northern Australia. Copeia, vol. 1977, no. 2, pp. 238-249. http://dx.doi. org/10.2307/1443905. 